URŠA HORVAT

E-mail: ursa.horvat@yahoo.com

University of Ljubljana,

Faculty of Maritime Studies and Transportation

Pot pomorščakov 4, SI-6320 Portorož, Republic of Slovenia
Intermodal Transport

Preliminary Communication

Accepted: Apr. 21, 2009

Approved: Sept. 15, 2010

\title{
POSSIBILITY OF INCREASING CONTAINER TRAFFIC IN THE PORT OF KOPER DUE TO INTRODUCING THE SEA MOTORWAY
}

\begin{abstract}
The aim of this paper is to present the possibility of introducing the motorway of the sea to the Port of Koper. Based on the present situation in the Port of Koper and the planned extension of the container terminal determined by the development plans of the Port of Koper, the paper presents the increase in the container transhipment due to the introduction of the motorway of the sea and its influence on the hinterland infrastructure.

For this purpose a simulation was introduced which shows the increase in container transhipment and its distribution between the road and railway part of the container terminal until the year 2015. The maximum capacity of the road and railway part of the container terminal presents two critical points which would be reached due to the introduction of the motorway of the sea to the Port of Koper. The consequence would be a change in the distribution ratio of transhipment between road and railway part of the container terminal. This would overturn the desired ratio of 30:70 (road: railway) determined by the guidelines of the White Paper.
\end{abstract}

\section{KEY WORDS}

Motorway of the sea, Port of Koper, container transhipment

\section{INTRODUCTION}

The present situation in the world in the field of freight traffic is implying the need of redirecting traffic flows as much as possible from heavily congested roads to environmentally friendlier, safer and generally more suitable means of transport, such as railways and motorways of the sea, as part of an integrated transport chain. Container shipping plays a key role in the modern global economic system. In 2007 a global port throughput was 466 million TEUs [1]

For the countries involved, the motorways of the sea present an important source of flow of goods containerized goods and vehicles. The Port of Koper is mostly interested in the connection with the sea motorway of south-eastern Europe, which would increase the container transhipment even more.
The empirical parts of this paper focus on the possibility of increasing container traffic because of the connection of the Port of Koper with the sea motorway of south-eastern Europe, and the consequences that would arise from the above mentioned connection especially the increase of flow of goods in the Port of Koper and its hinterland. The Port of Koper, because of its present condition, already needs urgent measures from the transport policy, which could significantly contribute to the development of the sea motorway in the Port of Koper and to a more harmonised transport system in general.

In maritime transport policy the European Commission promotes the Motorways of the sea as one of the solutions of reducing road congestion [2]. Motorways of the sea will thus improve the access to markets throughout Europe and bring relief to overstretched European road system. Fuller use will have to be made not only of maritime transport resources, but also of the potential of rail and inland waterways, as part of an integrated transport chain. This is the Community added value of motorways of the sea [3]. The need to shift goods from road to underused transport capacity led the European Commission to embark on the development of two important policies: one concerning short sea shipping and the other concerning the transEuropean transport network [4].

What the influence of the potential motorways of the sea will be like on the increase of the container transhipment at the Port of Koper is presented in this paper. However, the increase in the container transhipment is limited by the capacity of the container terminal as such. For this purpose the capacity of the container terminal at the Port of Koper ought to increase in the following years, especially by building more piers, but at the same time it ought to limit the increase in the transhipment capacity.

The problem that is brought up when discussing both the present as well as the future quantity of transhipment at the Port of Koper is the connection of the Port of Koper with the hinterland. The connection has been established by both road and railway infrastruc- 
ture. The problem lies mainly in inappropriate hinterland connections of the Port of Koper, which present a bottleneck due to the low capacity of railway and long transit times.

The paper would like, on the basis of the limitations at the Port of Koper, to introduce a simulation of possibilities of the increase in the container transhipment as consequence of the connection to a sea motorway.

\section{CONTAINER TRANSHIPMENT AT THE PORT OF KOPER AND OTHER NORTH-MEDITERRANEAN PORTS}

The next chapter presents the current situation of container transhipment, and its growth up to now in the Port of Koper and other North Mediterranean ports. This presents a foundation for further calculation of possible growth of container traffic as consequence of linking the Port of Koper to the sea motorway.

\subsection{Analysis of the present condition and general assumptions}

The Port of Koper is a multipurpose port, equipped and trained as transhipment and storage for any kind of goods. They achieved 15.4 million of ton of transhipment in 2007 and exceeded the amount of transhipment in 2006 by $10 \%$. Container transhipment amounted to a record 305,648 TEUs. The connection of the Port of Koper with the sea motorway would ad- ditionally increase an already constant growth of traffic up to its available capacity.

Displays are made on the basis of data gained from the Port of Koper (Table 1), Slovene railways and on the basis of the following assumptions:

- data for January (2006-2008) in Table 1 are generalised per year;

- transhipment between road and rail is in proportion 30:70;

- container deliveries within the Port of Koper territory are not taken into consideration, although they represent a considerable share of port container traffic;

- transhipment - unloading of cargo from one vessel and loading it aboard another vessel, even if cargo stands on terminal for some time before it is shipped again, is not analysed;

- container traffic in the year 2008 is by $26 \%$ larger than in the year 2007 (comparison of the first two months 2008/2007);

\subsection{Comparison of container transhipment at the Port of Koper with other North-Mediterranean ports}

The ports of the North Mediterranean included in the sea motorway of the south-eastern Europe are part of the TEN-T network which ought to be established by the year 2010. Sea motorways refer mainly to the development of key sea routes and connections between

Table 1 - Container transhipment in the Port of Koper

\begin{tabular}{|c|c|c|c|c|c|c|c|c|}
\hline Month & & 20'empty & $20^{\prime}$ full & 40' empty & $40^{\prime}$ full & Total & TEU & Sum of TEU \\
\hline \multirow{6}{*}{ Jan.06 } & Vessel arrival & 71 & 2,172 & 392 & 2,423 & 5,058 & 7,873 & 16,098 \\
\hline & Vessel departure & 435 & 1,444 & 888 & 2,285 & 5,052 & 8,225 & \\
\hline & Truck arrival & 836 & 396 & 725 & 581 & 2,538 & 3,844 & 7,769 \\
\hline & Truck departure & 420 & 871 & 458 & 859 & 2,608 & 3,925 & \\
\hline & Railway arrival & 371 & 864 & 563 & 858 & 2,656 & 4,077 & 8,767 \\
\hline & Railway departure & 551 & 1,125 & 324 & 1,183 & 3,183 & 4,690 & \\
\hline \multirow{6}{*}{ Jan.07 } & Vessel arrival & 424 & 3,155 & 337 & 3,787 & 7,703 & 11,827 & 22,881 \\
\hline & Vessel departure & 1,244 & 1,938 & 2,078 & 1,858 & 7,118 & 11,054 & \\
\hline & Truck arrival & 993 & 412 & 1.044 & 660 & 3,109 & 4,813 & 9,703 \\
\hline & Truck departure & 394 & 1,078 & 533 & 1,176 & 3,181 & 4,890 & \\
\hline & Railway arrival & 628 & 836 & 1,318 & 730 & 3,512 & 5,560 & 12,262 \\
\hline & Railway departure & 293 & 1,675 & 243 & 2,124 & 4,335 & 6,702 & \\
\hline \multirow{6}{*}{ Jan.08 } & Vessel arrival & 68 & 3,725 & 172 & 5,322 & 9,287 & 14,781 & 27,742 \\
\hline & Vessel departure & 1,123 & 1,746 & 2,981 & 2,065 & 7,915 & 12,961 & \\
\hline & Truck arrival & 1,022 & 513 & 1,622 & 753 & 3,910 & 6,285 & 12,709 \\
\hline & Truck departure & 457 & 1,191 & 539 & 1,849 & 4,036 & 6,424 & \\
\hline & Railway arrival & 619 & 1,063 & 2,033 & 827 & 4,542 & 7,402 & 16,023 \\
\hline & Railway departure & 421 & 1,816 & 274 & 2,918 & 5,429 & 8,621 & \\
\hline
\end{tabular}

Source: Statistical data of the Port of Koper 
Table 2 - Container transhipment at North-Mediterranean ports from 2005 to 2007 in TEU and growth index

\begin{tabular}{||l||c|c|c|c|c||}
\hline & 2005 & 2006 & 2007 & $I_{06 / 05}$ & I07/06 $^{\mid}$ \\
\hline \hline Koper & 179,745 & 218,970 & 305,648 & 121.82 & 139.58 \\
\hline Venice & 289,860 & 316,641 & 329,512 & 109.24 & 104.06 \\
\hline Trieste & 189,932 & 210,225 & 256,016 & 110.68 & 121.78 \\
\hline Rijeka & 76,258 & 94,390 & 145,040 & 123.78 & 153.66 \\
\hline
\end{tabular}

Source: Statistical data of the Port of Koper, Venice, Trieste, Rijeka

the member states of the European Union, and at the same time they provide the possibility of connections with the neighbouring states.

The paper also discusses the importance of the North-Mediterranean ports of Koper, Trieste, Veniceand Rijeka that are situated in three different countries. Their importance lies in their strategic position reflected in container transhipment which has seen a significant increase in the recent years as shown in Table 2.

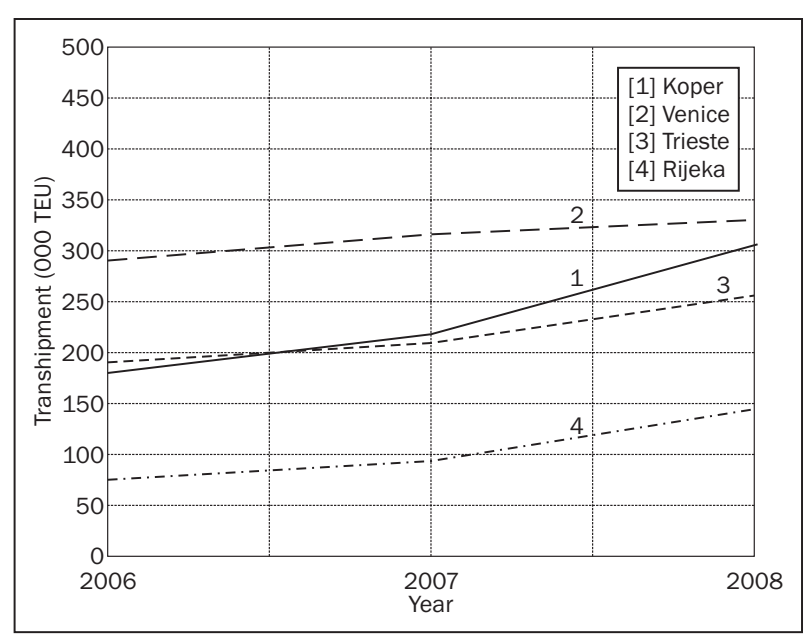

Figure 1 - Container transhipment at North-Mediterranean ports

Source: Set by the author according to statistical data of the Port of Koper, Venice, Trieste, Rijeka

The largest increase in container transhipment can be observed at the Ports of Koper and Rijeka. The increase can be partly subscribed to the introduction of a sea motorway and partly to a rather well-developed hinterland infrastructure and simplified customs procedures. For instance, the procedure of writing out a transit document in Trieste is much longer in comparison to the same procedure in Koper, which is, logically, one of the main reasons for diverting cargo from the Italian ports to the Port of Koper.

\section{LIMITATIONS OF INCREASE IN TRANSHIPMENT AT THE PORT OF KOPER}

The following chapter introduces those limitations that prevent an uncontrolled increase in container transhipment as a consequence of the connection to a sea motorway. Partly, the increase is limited by the capacity of the container terminal and partly by the hinterland infrastructure, in particular railway hinterland structure.

\subsection{Limited increase in transhipment by the capacity of container terminal}

By introducing simulations a $10 \%$-increase in container transhipment has been predicted from the year 2009 on generated by the sea motorway. The abovementioned supposition is based on the data about transhipment at the North-Mediterranean ports showing a constant growth (Table 2). At the Port of Koper the growth was more than $20 \%$ in the years 2005 and 2006, and a little bit less than 40\% in the years 2006 and 2007. However, the increase in container transhipment at the Port of Koper has been limited by the maximum capacity of the container terminal. This has been determined by the development plans of the Port of Koper as regards building more piers. In case of a more than a $10 \%$-increase the above-mentioned maximum capacity of the container terminal would be surpassed. The data about the increase in the capacity of the container terminal and the present and planned container transhipment (from the year 2009 on) are shown in Table 3.

Figure 2 shows how the capacities of container terminal have already changed and will change in the future as well as in accordance with development phases of construction of piers in the Port of Koper. Besides the above-mentioned assumptions the figure also shows the present and future container tranship-

Table 3 - Container transhipment and container terminal capacity by years

\begin{tabular}{||l||c|c|c|c|c|c|c|c|c|c||}
\hline \multicolumn{1}{|c|}{ Year } & 2006 & 2007 & 2008 & 2009 & 2010 & 2011 & 2012 & 2013 & 2014 & 2015 \\
\hline \hline $\begin{array}{l}\text { Capacity } \\
(1000 \text { TEU) }\end{array}$ & 300 & 350 & 400 & 600 & 600 & 600 & 800 & 800 & 800 & 1,000 \\
\hline $\begin{array}{l}\text { Traffic - } \\
10 \text { percent growth }\end{array}$ & 218,970 & 305,648 & 385,117 & 423,629 & 465,992 & 512,591 & 563,580 & 620,235 & 682,259 & 750,485 \\
\hline \hline
\end{tabular}

Source: Set by the author according to statistical data of the Port of Koper 


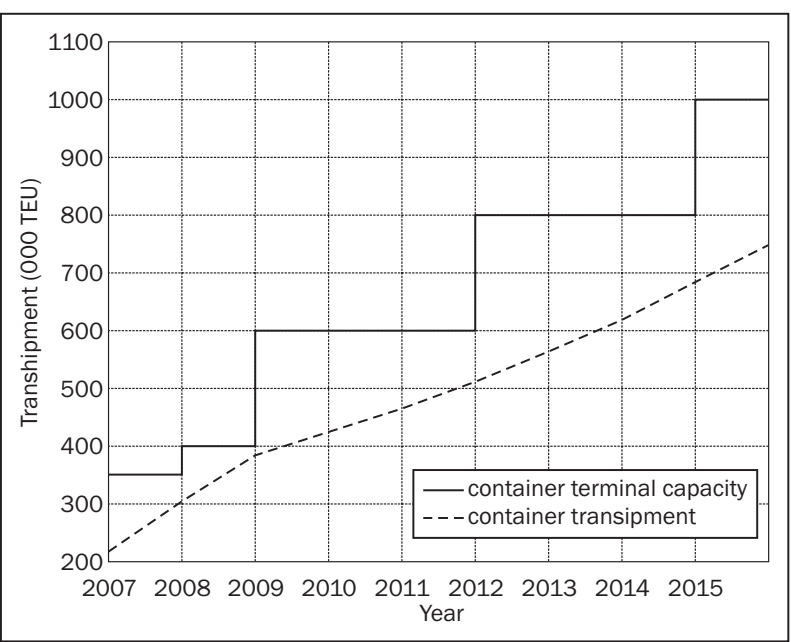

Figure 2 - Variations of container transhipment according to container terminal capacity from 2007 to 2015

Source: Set by the author according to statistical data of the Port of Koper

ment based on the assumptions mentioned in the beginning of this paper.

\subsection{Limited increase in transhipment with the capacity of road and railway part of the container terminal}

At the moment the capacity of the Port of Koper, the road part of container terminal is 250 trucks per day. The problem is how to define the capacity of the railway container terminal, which has not been precisely defined.

According to the information received by the department for public relations of the Port of Koper, they are able to load/discharge a maximum of 7 wagon sets per day (where 1 wagon set is equal to 1 loaded or 1 discharged wagon set).

According to the information received by the Section for freight traffic Koper (Slovenian railways) the Port of Koper should be able to load/discharge a maximum of 7 wagon sets per day (where 1 wagon set is equal to 1 discharged +1 loaded wagon set, total 14 trains per day). This would be possible only if all operations went according to plan (punctual deliveries, no mechanical breakdowns, all necessary documentation provided on time...). But according to their past experience, the optimum number of loaded/discharged wagon sets should be 6 , which means 6 loadings and 6 discharges, in total 12 trains per day.
Other cargoes do not have any influence on the number of trains that rail container terminal can provide. The Slovenian railways are only limited by the number of trains from Koper per day (approximately 30 trains per day, when there are no blockades or any other barriers) and daily operational situation: $7 x$ ore, $6 x$ fuel, $2 x$ bauxite, $5 x$ coal, $2 x$ phosphates, $1 x$ empty wagons from wood, $1 x$ cars, $1 x$ sheet metal. Thus, there are 25 regular trains that depart from the Port of Koper every day. Then we have to add also approximately 3-4 trains from cargoes that are being discharged (sheet metal, pipes, paper, scrap metal, cellulose, cars...) and wagon sets which are not used for re-export, but need to be dispatched from Koper. In case these wagon sets were not dispatched from Koper a major traffic jam would occur (lack of empty tracks), which would consequently have an influence on all kind of cargoes as delivery and driveway would be hindered. To the above mentioned, trains loaded with containers (block trains and shuttles) have to be added. To sum up, this means that in the Port of Koper operational decisions, such as for instance which cargo will be given priority, are made on a daily basis.

\section{SIMULATION OF ROAD AND RAIL TRANSPORT OF CONTAINERS}

As result of previously unequal information from the Slovenian railways and the Port of Koper regarding daily plans of the Section for freight traffic Koper (approximately 9 trains per day) and the information about TEUs loaded and discharged from wagons in January 2008 (a total of 16,023 TEUs, which means an average of 534 TEUs per day), a maximum of 10 loaded/discharged wagon sets (5x2 wagon sets) per day for graphical demonstration is assumed, which is also the most realistic presumption according to all the previously mentioned resources.

The calculations below (Table 6) are based on the assumption that the Port of Koper is able to load/discharge 10 wagon sets per day, and on the basis of the assumptions presented in Table 5. Table 4 also presents the maximum rail container transhipment per year for 7, 12 and 14 wagon sets per day.

Figure 3 and Table 6 show that according to the ideal scenario, the reserve with regard to the existent infrastructure and rail container traffic in the year 2008 $(192,276$ TEUs) is 77,724 TEUs. This means that a number of trains could increase by 3 per day, both ar-

Table 4 - The maximum capacity of rail transhipment per year according to realistic and ideal scenario taking into account daily number of trains

\begin{tabular}{|l||c|c|c|c||}
\hline \multicolumn{1}{|c|}{ Maximum } & 10 trains & 7 trains & 12 trains & 14 trains \\
\hline \hline Realistic (TEU) & 198,000 & 138,600 & 237,600 & 277,200 \\
\hline Ideal (TEU) & 270,000 & 189,000 & 324,000 & 378,000 \\
\hline
\end{tabular}

Source: Set by the author according to statistical data of the Slovenian railways 
Table 5 - Assumptions concerning road and railway activity

\begin{tabular}{|c|c|}
\hline \multicolumn{2}{|l|}{ ASSUMPTIONS } \\
\hline Railway & Road \\
\hline $\begin{array}{l}\text { - } 360 \text { working days; } \\
\text { - wagonset length is approximately } 500 \mathrm{~m}, 25 \text { 4-axle wagons); } \\
\text { - maximum capacity of } 10 \text { trains per day; } \\
\text { - ideal - Rdmax: the Port of Koper loads/discharges } 10 \text { trains per day } \\
\quad(5+5 \text { trains, that equal } 750 \text { TEUs per day); } \\
\text { - realistic - Rrmax (based on present situation): the Port of Koper loads/ } \\
\quad \text { discharges on average } 55 \text { TEUs per train (550 TEU per day). }\end{array}$ & $\begin{array}{l}\text { - Road container terminal works on average } 26 \\
\text { days per month (Monday-Saturday); } \\
\text { - maximum capacity of road container terminal } \\
\text { is } 250 \text { trucks per day; } \\
\text { - } 2 \text { TEUs per truck. }\end{array}$ \\
\hline
\end{tabular}

Source: Set by the author according to statistical data of the Port of Koper and the Slovenian Railways

$C_{i}=\left(P_{i}-P_{i-1}\right) * 0.3+C_{i-1}$

$i \geq 2009$

$R_{i}=\left(P_{i}-P_{i-1}\right) * 0.7+R_{i-1}$

$i \geq 2009$

$D r_{i}=\left(R_{i}-R r_{\max }\right)+C_{i}$

$i \geq 2009 ; R r_{\max }=198,000 \mathrm{TEU}$

$\operatorname{Did}_{i}=\left(R_{i}-R d_{\text {max }}\right)+C_{i}$

$i \geq 2011 ; R d_{\max }=270,000$ TEU

Table 6 - Road and railway transport from 2006 to 2015

\begin{tabular}{|c|c|c|c|c|c|c|c|c|}
\hline \multirow{3}{*}{$\begin{array}{l}\text { Year } \\
\text { (i) }\end{array}$} & \multirow{3}{*}{ Capacity } & \multirow{3}{*}{$\begin{array}{l}\text { Traffic - } 10 \% \\
\text { growth }(\mathrm{P})\end{array}$} & \multirow{3}{*}{$\begin{array}{l}\text { Road traffic } \\
\text { (C) }\end{array}$} & \multirow{3}{*}{$\begin{array}{l}\text { Railway } \\
\text { traffic (R) }\end{array}$} & \multicolumn{4}{|c|}{ Road + railway difference (D) } \\
\hline & & & & & \multicolumn{2}{|c|}{ Realistic (Dr) } & \multicolumn{2}{|c|}{ Ideal (Did) } \\
\hline & & & & & Sum & /day & Sum & /day \\
\hline 2006 & 300,000 & 218,970 & 93,228 & 105,204 & 93,228 & 150 & 93,228 & 150 \\
\hline 2007 & 350,000 & 305,648 & 116,436 & 147,144 & 116,436 & 187 & 116,436 & 187 \\
\hline 2008 & 400,000 & 385,117 & 152,508 & 192,276 & 152,508 & 245 & 152,508 & 245 \\
\hline 2009 & 600,000 & 423,629 & 164,062 & 219,234 & 185,296 & 297 & 164,062 & 263 \\
\hline 2010 & 600,000 & 365,992 & 189,480 & 248,888 & 240,368 & 385 & 189,480 & 304 \\
\hline 2011 & 600,000 & 512,591 & 203,460 & 281,507 & 286,967 & 460 & 214,967 & 345 \\
\hline 2012 & 800,000 & 563,580 & 218,757 & 317,199 & 337,956 & 542 & 265,956 & 427 \\
\hline 2013 & 800,000 & 620,235 & 235,754 & 356,858 & 394,612 & 633 & 322,612 & 517 \\
\hline 2014 & 800,000 & 682,259 & 254,361 & 400,275 & 456,636 & 732 & 384,636 & 616 \\
\hline 2015 & $1,000,000$ & 750,485 & 274,829 & 448,033 & \multicolumn{4}{|c|}{ Double track from Koper to Divača } \\
\hline
\end{tabular}

Source: Set by the author according to statistical data of the Port of Koper

Legend:

\begin{tabular}{|l|l|}
\hline & Years, in which cargo is divided between road and rail in ratio 30:70. \\
\hline & Years, in which cargo is redirected from rail to road. \\
\hline & Years, in which railway transhipment exceeds capacity according to realistic or ideal scenario. \\
\hline
\end{tabular}

rival and departure in total (this actually means 1.4 trains per day). However, according to the present situation the reserve is 477 TEUs per month, which means that the railway can accommodate only additional 16 TEUs per day. The introduction of a sea motorway to the Port of Koper in the year 2009 by the realistic scenario would change the ratio between road traffic and rail traffic from 30:70 to only 85:15.

From all the above mentioned it is clear that the majority of cargo should be diverted to road, because without the raising of the second track Koper-Divača or additional mechanisation, further growth is not possible (limited capacity of rail container terminal).

In the year 2007 the entire container transhipment amounted to 305,648 TEUs and in the year 2008 to
385,117 TEUs and in the year 2009, under the assumption of introducing a sea motorway to the Port of Koper and with this $10 \%$ growth of transhipment, it would increase to 423,629 TEUs. Based on the assumption that the cargo is distributed between road and rail in ratio 30:70 (present situation), that would mean additional 2,247 TEUs per month (26,958 TEUs per year) and 219,234 TEUs in the year 2009. Taking into account a realistic scenario (maximum capacity of rail container terminal is 198,000 TEUs per year) the railways are incapable to accept this amount of cargo, so that this is why the difference in transhipment of 21,234 TEUs per year must be redirected to the road, which is practically without limitation. However, on the other hand container terminal is limited by mecha- 


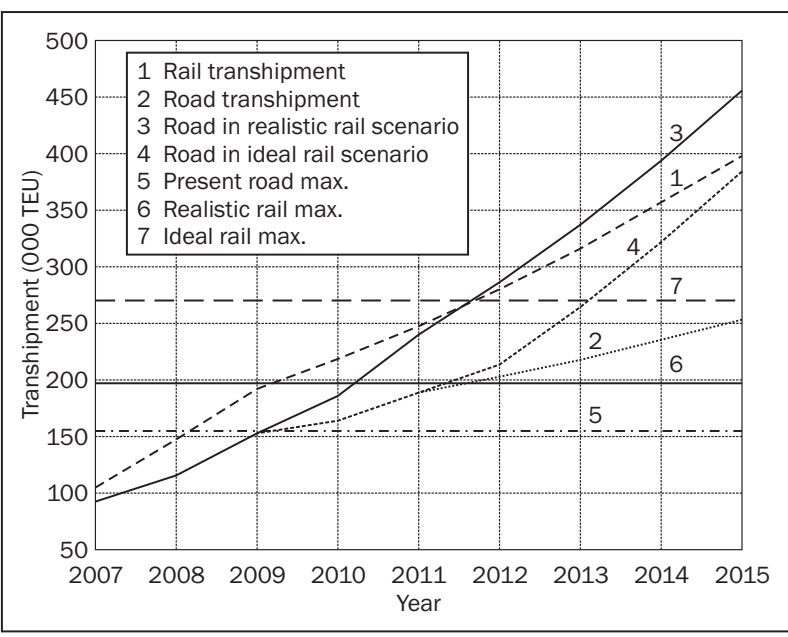

Figure 3 - Road and rail container transhipment in the years 2007-2015

Source: Set by the author according to statistical data of the Port of Koper

nisation and therefore, by the maximum number of loaded/discharged containers, which restricts further development. At the moment the maximum capacity of the road container terminal is 250 trucks per day and can be increased with a purchase of additional mechanisation.

Figure 3 shows that the reserve of road container terminal in the year 2008 is 3,492 TEUs per year, which means about 5 additional trucks per day. The introduction of a sea motorway in the year 2009 which would increase container transhipment by an extra 11,554 TEUs per year (30 percent of the 10 percent growth) would exceed the capacity of loaded/ discharged trucks. In this case and in case of further growth it would therefore be necessary to provide additional mechanization, because railways are not capable of accepting larger amounts of cargo until the year 2015.

Taking into account a realistic scenario, by which railways are not capable of accepting any additional cargo, any extra cargo should be redirected entirely to the road by the year 2015 . At the moment railways can accept only additional 5,724 TEUs per year. That would increase road traffic from 13,672 TEUs per month (in the year 2009) to 15,441 TEUs per month. This would exceed the actual maximum capacity of 13,000 TEUs per month (250 trucks per day) for 94 TEUs per day. Now the capacity of road container terminal should be at least 297 trucks per day. With the assumption of $10 \%$ growth the road container traffic would have to increase its capacity to 385 trucks per day $(20,020$ TEUs per month) in the year 2010 and to 732 trucks per day in the year 2014, before the opening of the second track between Koper and Divača.

From all the above mentioned predictions it can be assumed that the road container terminal has the opportunity to develop further with a purchase of ad- ditional mechanisation, and consequently to increase the capacity of loaded/discharged trucks. No matter which scenario is taken into consideration railways will be fully exploited by the year 2011 at the latest.

The situation is different when taking into account the information received from the Port of Koper and maximum 7 loaded/discharged wagon sets per day, where capacity was already exceeded in the year 2007 using the realistic scenario. That means that since 2007 additional cargo has been already redirected to road. Using an ideal scenario this will happen in 2008.

Taking into account the information received by the Slovenian railways about the optimum of 12 and maximum of 14 loaded and discharged wagon sets per day, the railways still have quite a lot of reserve until it exceeds its maximum - according both to the realistic and the ideal scenario. Using a realistic scenario this will happen in the year 2010 (for 12 wagon sets) or in the year 2011 (for 14 wagon sets). Using the ideal scenario this will happen in the year 2013 (for 12 wagon sets) or in the year 2014 (for 14 wagon sets).

\section{CONCLUSION}

The Port of Koper represents a connecting link between the Slovene and the European economy hinterland and overseas countries and is therefore a strong generator of freight flows. The Port of Koper intends to establish a sea motorway, and this intention is in the framework of intermodality to increase or to divert as much cargo as possible (containers, vehicles) to environmentally friendlier maritime transport. For Slovenia this will mean increased amounts of goods in transit. Analysed container traffic will in the next years mean additional load connected with the introduction of a sea motorway. A large number of containers already arrive and depart from the Port of Koper also by road, because railway with its infrastructure (especially the one railway track from Koper to Divača) very often forms a bottleneck.

In the year 2008, according to the ideal scenario, that is introducing maximum exploitation, the railway container traffic can accept merely 78,000 TEUs more per year. This means traffic could increase only by less than 3 trains per day, both in arrivals and departures. According to the realistic scenario it has the possibility of accepting only 16 TEUs more per day (1 train has ca. 55-75 TEUs).

With the introduction of a sea motorway in the year 2009, which would generate a growth of container transhipment by $10 \%$, a proportion between road and railway would change from previous $30: 70$ to only $85: 15$ in 2009. From here onward all additionally generated cargo will have to be diverted to road.

Thus, it would be necessary to increase also the capacity of road part of container traffic that momentarily 
amounts to 250 trucks per day. Road container traffic would therefore have to accept, beside its share, also the cargo diverted to road because of the limited rail capacity. For this reason the capacity of road container traffic would have to increase up to 297 trucks per day in the year 2009 and up to 732 trucks per day till the year 2015, because railway is not capable of accepting any additional cargo until the construction of the second railway track in 2015.

Taking into account the poor existing condition of the Slovene railways, the distribution of traffic considering the market share of different means of transport in Slovenia also develops in the direction of increased road freight transport and at the same time rail transport decreases because of increased road transport. By doing so, traffic trends move away from the principles of sustainable development. For this purpose it would be necessary to encourage redirection of road freight traffic to rail with different measures of transport policy. But first of all the Slovenian railway system should be extended and modernized. This presents the base for improving transport services and assuring adequate efficiency of network for present and future traffic flows. The fact is that the efficiency of an individual corridor is defined by the efficiency of its worst link.

Therefore, there exists a risk that in case of a too slow extension of now unsuitable railway connection, the freight currents will be diverted to roads outside Slovenia and to the neighbouring ports, especially to the ports of Trieste and Rijeka, which represent strong competition to the Port of Koper on such a small area, as the northern Adriatic Sea territory.

A future trend in the transport branch indicates a demand for redirection of the flow of goods from roads to environmentally friendlier means of transport, in particular, the railways and motorways of the sea [8]. Without a suitable railway connection with the hinterland, the introduction of a motorway of the sea would be, for Slovenia, just an additional burden on roads and that is not compatible with the transport policy of the Republic of Slovenia and the orientations provided in the White Paper.

\section{URŠA HORVAT}

E-mail: ursa.horvat@yahoo.com

Univerza v Ljubljani, Fakulteta za pomorstvo in promet Pot pomorščakov 4, 6320 Portorož, Republika Slovenija

\section{POVZETEK}

\section{MOŽNOST POVEČANJA KONTEJNERSKEGA PROMETA V LUKI KOPER ZARADI VPELJAVE POMORSKE AVTOCESTE}

$\checkmark$ referatu je predstavljena možnost vpeljave pomorske avtoceste $v$ Luko Koper. Na podlagi sedanjega stanja Luke
Koper in načrtovane širitve kontejnerskega terminala, je predstavljeno povečanje kontejnerskega pretovora, zaradi vpeljave pomorske avtoceste ter njen vpliv na zaledno infrastrukturo.

$V$ ta namen je bila izdelana simulacija, ki prikazuje povečanje kontejnerskega pretovora in njegovo porazdelitev med cestni in železniški del kontejnerskega terminala do leta 2015. Maksimalni kapaciteti cestnega in železniškega dela kontejnerskega terminala določata kritični točki, do katerih bi prišlo zaradi vpeljave pomorske avtoceste. Posledica bi bila sprememba $v$ razmerju porazdelitve tovora med cestnim in železniškim delom kontejnerskega terminala zaradi česar bi se želeno razmerje (30:70 v korist železnice) določeno s smernicami bele knjige porušilo.

\section{KLUUČNE BESEDE}

pomorska avtocesta, luka Koper, kontejnerski pretovor

\section{LITERATURE}

[1] http://www.crsl.com/acatalog/Shipping_Review_and_ Outlook.

[2] http://ec.europa.eu/transport/maritime/doc/maritime_transport_policy_en.pdf

[3] http://www.transport-research.info/Upload/Documents/200608/20060831_100831_88503_Sea_ Motorways.pdf

[4] Paixão Casaca A.C., Marlow P. B.: The Impact of the Trans-European Transport Networks on the Development of Short Sea Shipping, Maritime Economics and Logistics, Vol. 9, No. 4, 2007, pp. 302-323.

[5] Brooks, M., Frost, J.D.: “Short Sea Shipping: A Canadian perspective." Maritime Policy \& Management, Vol. 31, No. 4, 2004, pp.393-407.

[6] Wiegmans, B. W., van der Hoest, A., Notteboom, T.: Port and terminal selection by deep-sea container operators, Maritime policy and management, Vol. 35, No. 6, 2008, pp. 517-534.

[7] Ng, K.Y.A.: Assessing the Attractiveness of Ports in the North European Container Transhipment Market: An Agenda for Future Research in Port Competition, Journal of Maritime Economics and Logistics, Vol. 8, No. 3, 2006, pp. 234-250.

[8] Beškovnik, B.: Importance of short sea shipping and sea motorways in the European and Slovenian transport policy, Pomorstvo, Vol. 20, No. 1, 2006, pp. 23-35.

[9] Internal material of Port of Koper.

[10] Internal material of Slovene Railways.

[11] Resolucija o nacionalnih razvojnih projektih za obdobje 2007-2023; Služba vlade RS za razvoj, October 2006. [URL: http://www.gov.si/rrs/util/bin.php? $\mathrm{id}=2006101718322902$ ].

[12] Koalicijazatrajnostnoprometnopolitiko; 7.2.2006.[URL: http://www.focus.si/index.php?node $=27 \& i d=122$ $\& s=$ arhiv]

[13] White Paper "European transport policy for 2010: time to decide"; European Commission, 2001. 